Tropical Journal of Pharmaceutical Research October 2019; 18 (10): 2101-2107

ISSN: $1596-5996$ (print); 1596-9827 (electronic)

(c) Pharmacotherapy Group, Faculty of Pharmacy, University of Benin, Benin City, 300001 Nigeria.

\title{
Phytoestrogen in cowpea (Vigna unguiculata L. Walp) (Fabaceae) extract reduces vaginal oxidative stress and increases proliferation of fibroblast in ovariectomized rats
}

\author{
Arika Indah Setyarini ${ }^{1}$, I Wayan Arsana Wiyasa ${ }^{2,3 *}$, Retty Ratnawati ${ }^{3}$, I Wayan \\ Agung Indrawan ${ }^{2,3}$ \\ ${ }^{1}$ Poltekkes Kemenkes Malang, Easy Java, Indonesia, ${ }^{2}$ Fertility Endocrinology and Reproduction Division, Department of \\ Obstetrics Gynecology, Saiful Anwar Public Hospital, ${ }^{3}$ Faculty of Medicine, 4Physiology Laboratory, Faculty of Medicine, \\ Brawijaya University, Malang, East Java, Indonesia
}

${ }^{*}$ For correspondence: Email: arsanawiyasa@gmail.com; Tel: +62-341-580993

Sent for review: 11 May 2019

Revised accepted: 27 September 2019

\begin{abstract}
Purpose: To evaluate the effects of a phytoestrogen extract of cowpea (Vigna unguiculata) on malondialdehyde (MDA) and superoxide dismutase (SOD) levels, mitogen-activated protein kinase (MAPK) activity, as well as proliferation of fibroblasts in ovariectomized rat vagina. This is with a view to identify the optimal dose of a phytoestrogen supplement for use during the menopausal period of women.

Methods: Wistar rats (Rattus norvegicus) were divided into five groups: negative control, ovariectomy, and ovariectomy groups treated with $1.25,2.5$, or $5 \mathrm{mg} / \mathrm{kg}$ of cowpea extract, respectively. The three doses were used to identify the optimal dose required to reduce vaginal oxidative stress and increase fibroblast proliferation in ovariectomized rats. After treatment, the ovariectomized rat vagina was assessed for SOD and MDA levels, MAPK activity, and fibroblast proliferation.

Results: Cowpea extract at a dose of 2.5 and $5 \mathrm{mg} / \mathrm{kg}$ caused significant reduction in SOD levels in the vaginal tissue of rats compared with control $(p<0.05)$. In contrast, cowpea extract at $1.25 \mathrm{mg} / \mathrm{kg}$ resulted in MDA levels similar to that of control rats $(p<0.05)$. Cowpea extract treatment had positive effects on SOD and MDA levels and on fibroblast proliferation. Increase in SOD levels in rat vagina was induced by increased MDA levels, which is characteristic of oxidative stress, while ovariectomy resulted in decreased MAPK activity.

Conclusion: Overall, the cowpea extract has no significant effect on MAPK activity or fibroblast proliferation. However, it has a significant effect on SOD and MDA levels and on fibroblast proliferation at a dose of $2.5 \mathrm{mg} / \mathrm{kg}$.
\end{abstract}

Keywords: Cowpea, Vigna unguiculata, Fibroblast proliferation, Ovariectomy

This is an Open Access article that uses a fund-ing model which does not charge readers or their institutions for access and distributed under the terms of the Creative Commons Attribution License (http://creativecommons.org/licenses/by/4.0) and the Budapest Open Access Initiative (http://www.budapestopenaccessinitiative.org/read), which permit unrestricted use, distribution, and reproduction in any medium, provided the original work is properly credited.

Tropical Journal of Pharmaceutical Research is indexed by Science Citation Index (SciSearch), Scopus, International Pharmaceutical Abstract, Chemical Abstracts, Embase, Index Copernicus, EBSCO, African Index Medicus, JournalSeek, Journal Citation Reports/Science Edition, Directory of Open Access Journals (DOAJ), African Journal Online, Bioline International, Open-J-Gate and Pharmacy Abstracts

\section{INTRODUCTION}

Menopause is an estrogen deficiency-related condition with several characteristics such as hot flashes, sweating, insomnia, vaginal dryness, and other symptoms. This condition usually affects those who are $>45-55$ years of age and typically starts with irregular menstruation or absence of menstruation [1]. Hypoestrogenemia in menopausal females also leads to a decrease 
in the antioxidant activity of estrogen, and increases the formation of free radical molecules or reactive oxygen species (ROS) [2]. The formation of ROS then causes oxidative stress characterized by increasing levels of malondialdehyde (MDA), which causes lipid peroxidation [3]. Superoxide dismutase (SOD) is an enzymatic antioxidant which protects cells from oxygen free radicals by catalyzing the conversion of radical anion superoxide to oxygen molecules and hydrogen peroxide [4].

Hypoestrogenemia in menopausal females also leads to a decrease in the antioxidant activity of estrogen, and increases the formation of free radical molecules or reactive oxygen species (ROS) [2]. The formation of ROS then causes oxidative stress characterized by increasing levels of malondialdehyde (MDA), which causes lipid peroxidation [3]. Superoxide dismutase (SOD) is an enzymatic antioxidant, which protects cells from oxygen free radicals by catalyzing the conversion of radical anion superoxide to oxygen molecules and hydrogen peroxide [4].

Fibroblast cells play an important role in maintaining vaginal elasticity by synthesizing collagen reticular and elastic fibers and carbohydrates such as a glycosaminoglycan, proteoglycan, and glycoprotein in the extracellular matrix $[7,8]$. High-performance liquid chromatography has shown that Vigna unguiculata has a higher concentration of genistein and daidzein than soybean $[9,10]$. This study studied the effects of a phytoestrogen extract of cowpea (Vigna unguiculata) on vaginal tissue of ovariectomized rats, by evaluating SOD levels, production of MDA, and fibroblast proliferation.

\section{EXPERIMENTAL}

\section{Sample preparation}

The rats used in this research were chosen according to several criteria based on previous research [10]. Wistar rats (Rattus norvegicus) were divided into five groups: negative control, ovariectomy, and ovariectomy treated with 1.25, 2.5 , and $5 \mathrm{mg} / \mathrm{kg}$ cowpea (Vigna unguiculata) extract. Ovariectomy procedures were conducted based on previous methods by Khajuria [11]. The weight of the rats was measured with a digital scale to calculate the dose of anesthetic. The abdominal hairs of rats were removed and the abdomen was scrubbed with ethanol. A transverse peritoneal incision was made from the centre of abdomen to the right side of the second nipple $(0.4-0.6 \mathrm{~cm})$ using a size 11 scalpel.
Adipose tissue was removed when the incision reached the cavum peritoneal until the uterine tube and ovarium could be identified.

The same procedures were applied to the left ovarium. Each organ was placed on a sterilized dish, and the uterine tube was tied and the ovarium was cut. The uterine tube was then placed back into the cavum peritoneal. Skin and muscle tissue were stitched together using catgut. The peritoneum and muscle were stitched using easily absorbed thread (3/10 ethicon chromic sutures), while the skin was stitched using non-absorbed thread (3/10 ethicon mersilk sutures). The resulting scar was sterilized with povidone iodine using aseptic techniques. After ovariectomy, the rats were placed in a cage at room temperature with controlled light (12 h dark, $12 \mathrm{~h}$ light) for 4 weeks with ad libitum feeding. Cowpea (Vigna unguiculata) extract was then administered orally to hypoestrogenic rats for 30 days.

This research was authorized by the Ethics Committee of Medical Faculty's Health Research of Brawijaya University (approval no. 556D/EC/KEPK/S2/10/2015). All procedures performed in studies involving animal subjects were in accordance with the ethical standards of the institutional and/or national research committee and with the 1964 Declaration of Helsinki and its later amendments [12].

\section{Measurement of SOD levels}

Rat vaginal tissue was weighed, washed with phosphate-buffered saline (PBS), and homogenized on ice in cold PBS (0.02 M, pH 7.4) using a homogenizer. Sonication was then performed for $2 \mathrm{~min}$ with a $20 \%$ amplitude to enhance the cell lysis process. The cells were centrifuged for $5 \mathrm{~min}$ at 12,000× $\mathrm{g}$, and SOD levels were measured using a colorimetric assay at $440 \mathrm{~nm}$ based on the manufacturer's protocol for the EnzyChrom Superoxide Dismutase Assay Kit (BioAssay Systems, Hayward, CA, USA). In this assay, superoxide $\left(\mathrm{O}^{2-}\right)$ is produced by the xanthine oxidase $(\mathrm{XO})$ reaction. The superoxide reacts with cell viability WST-1 colorimetric assay, resulting in a colored product that can be detected at $440 \mathrm{nM}$.

Measurements were performed in $30 \mathrm{~mL}$ of washing buffer diluted into $750 \mathrm{~mL}$ of deionized water. SOD standard (3 U/mL) was obtained by mixing $8 \mu \mathrm{L}$ of SOD enzyme with $392 \mu \mathrm{L}$ of diluent. Each sample was transferred in $20 \mu \mathrm{L}$ to a different well. The working reagent was prepared by mixing $160 \mu \mathrm{L}$ of assay buffer, $5 \mu \mathrm{L}$ of xanthine, and $5 \mu \mathrm{L}$ of WST-1. The working 
reagent was then transferred into each well, followed by shaking of the plate to mix the reagents. The diluted XO enzyme (1:2 in $20 \mu \mathrm{L})$ was added to each well, followed by shaking of the plate. The plate was incubated for $60 \mathrm{~min}$ at room temperature $\left(25^{\circ} \mathrm{C}\right)$, and the absorbance was measured at $440 \mathrm{nM}$.

\section{Determination of malondialdehyde levels}

(MDA)

The MDA assay was based on the chromogenic reaction between $N$-methyl-2-phenylindole and MDA at $45^{\circ} \mathrm{C}$, resulting in a specific chromogen, 4-hydroxyalkenal, that was detected by absorbance at $586 \mathrm{nM}$. This chromogen was specifically produced in cells that underwent lipid peroxidation. Rat vaginal tissue was homogenized in PBS and the MDA concentration was measured using the fresh weight of vaginal tissue of the protein homogenate. The MDA level was measured using the BIOXYTECH MDA-586 spectrophotometric assay for MDA according to the manufacturer's protocol (Percipio Biosciences, Burlingame, CA, USA).

\section{Evaluation of fibroblast proliferation and MAPK activity}

Fibroblast proliferation and MAPK activity were measured using immunohistochemical methods. Fibroblast proliferation was evaluated using proliferating cell nuclear antigen (PCNA) as a primary antigen with incubation at $4^{\circ} \mathrm{C}$ overnight with the appropriate antibody. Ultra Tek AntiPolivalent (Scytek, West Logan, UT, USA) was used as a secondary antibody and was incubated at room temperature for $10 \mathrm{~min}$. Slides of rat vagina tissue were first deparaffinized by incubating the slides in xylene for $15 \mathrm{~min}$ (three times). The tissue slides were then washed with an alcohol series (100\%, $90 \%, 80 \%, 70 \%$, and $30 \%$ ) and distilled water for 5 min for each wash. Each slide was then washed four times with buffer ( $\mathrm{pH} 7.4)$ and incubated with $3 \%$ hydrogen peroxide for $10 \mathrm{~min}$. The anti-PCNA primary antibody was applied and incubated at $4^{\circ} \mathrm{C}$ overnight. Ultra Tek HRP (Ultra Tech, Merrick, NY, USA) was applied and incubated for $10 \mathrm{~min}$ at room temperature. Each step was followed by four rinses in PBS.

Four drops $(200 \mu \mathrm{L})$ of DAB Chromogen (Biocare Medical, Pacheco, CA, USA) was added to the $\mathrm{DAB}$ substrate tissue and the samples were incubated for 5 - $15 \mathrm{~min}$, depending on the desired staining intensity. A permanent mounting medium was applied to the coverslip. To measure MAPK activity, the prepared tissue slides were treated similarly to the immunohistochemical method used for fibroblast proliferation, but the primary antibody was anti-pERK $1 \frac{1}{2}$ (Tyr 204): sc-101760 (Bioss, Woburn, MA, USA). After mounting with entellan, the MAPK activity and fibroblast proliferation were measured using a light microscope at 400x magnification. Brown-colored, DAB-positive samples indicated MAPK activity, and samples lacking MAPK activity were colored purple as a result of Mayer's hematoxylin nuclear staining.

\section{Statistical analysis}

Statistical analysis was performed using one-way analysis of variance followed by Tukey's post hoc tests, at a significance level of $p=0.05$ and a confidence level of $95 \%(\alpha=0.05)$, using SPSS 16.0 for Windows software.

\section{RESULTS}

The SOD level in ovariectomized rats was almost two-fold greater than that of the control rats, with average concentrations of $3.26 \mathrm{U} / \mathrm{ml}$ and 1.97 $\mathrm{U} / \mathrm{mL}$, respectively. Administration of cowpea ( $\mathrm{V}$. unguiculata) extract after ovariectomy resulted in significant decreases in SOD levels at each concentration relative to the untreated rats (Figure 1). The lowest SOD level of $1.53 \mathrm{U} / \mathrm{mL}$ was obtained from extract treatment with 5 $\mathrm{mg} / \mathrm{kg}$. The control group and all the treatment groups showed similar SOD concentrations of $1.97,2.17,1.67$, and $1.53 \mathrm{U} / \mathrm{mL}$ for $\mathrm{P} 1, \mathrm{P} 2$, and P3 respectively with no significant differences. Increasing concentrations of cowpea ( $\mathrm{V}$. unguiculata) extract resulted in decreased SOD levels.

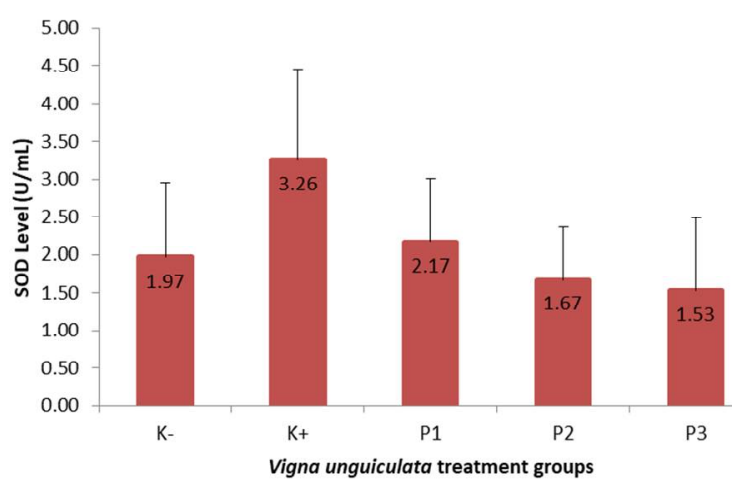

Figure 1: SOD levels were elevated significantly after ovariectomy $(p<0.05)$. Treatment with cowpea ( $V$. unguiculata) extract resulted in decreased SOD levels in a dose-dependent manner. $\mathrm{K}-$, negative control; $\mathrm{K}+$, untreated ovariectomized rats; $\mathrm{P} 1$, treated with cowpea (V. unguiculata) extract at $1.25 \mathrm{mg} / \mathrm{kg}$; P2, treated with $2.5 \mathrm{mg} / \mathrm{kg}$; and P3, treated with $5 \mathrm{mg} / \mathrm{kg}$

Similar to the SOD levels, the MDA levels showed a significant decrease after treatment 
with cowpea ( $V$. unguiculata) extract (Figure 2). Ovariectomy elevated the MDA levels to 0.57 $\mu \mathrm{M}$, almost two-fold greater than in the control group. Cowpea (V. unguiculata) extract significantly decreased the MDA levels after ovariectomy compared with the ovariectomy group $(\mathrm{K}+)$, and produced levels similar to those of the control group. The lowest MDA concentration of $0.24 \mu \mathrm{M}$ was obtained using a cowpea ( $V$. unguiculata) extract treatment of 2.5 $\mathrm{mg} / \mathrm{kg}$.

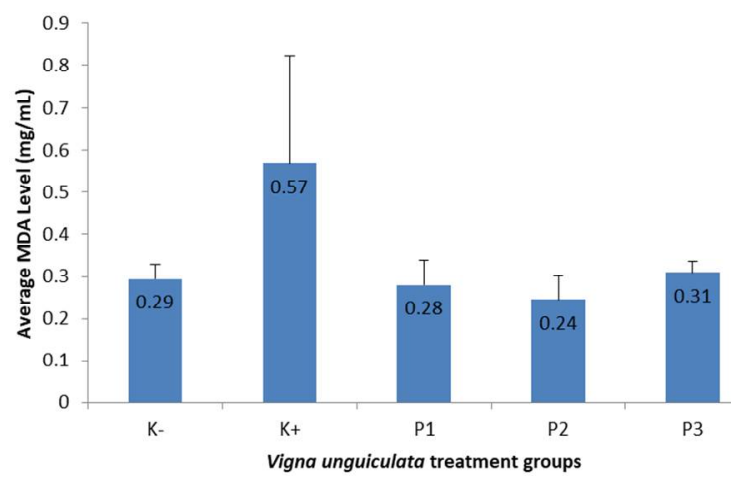

Figure 2: Effect of cowpea (V. unguiculata) extract treatment on malondialdehyde (MDA) levels ( $p<$ $0.05)$. The greatest decrease was observed after treatment with $2.5 \mathrm{mg} / \mathrm{kg}$. $\mathrm{K}-$, negative control; $\mathrm{K}_{+}$, untreated ovariectomized rats; $\mathrm{P} 1$, treated with 1.25 $\mathrm{mg} / \mathrm{kg}$; $\mathrm{P} 2$, treated with $2.5 \mathrm{mg} / \mathrm{kg}$; and $\mathrm{P} 3$, treated with $5 \mathrm{mg} / \mathrm{kg}$

Ovariectomy resulted in a decrease in MAPK activity (Figure 3) from $59.99 \%$ (K-) to $46.3 \%$ $(\mathrm{K}+)$. The highest level of MAPK activity was obtained with cowpea ( $V$. unguiculata) extract treatment at a dose of $2.5 \mathrm{mg} / \mathrm{kg}(62.05 \%)$. However, in general, there were no significant differences among the groups. Therefore, it was probable that ovariectomy did not directly affect MAPK activity.

The administration of cowpea ( $V$. unguiculata) extract at all doses did not affect the survival of fibroblasts on ovariectomized rats. Based on the results shown in Figure 4, ovariectomy resulted in a significant decrease in fibroblast proliferation to $48.15 \%$. Treatment with cowpea (V. unguiculata) extract at dose of $2.5 \mathrm{mg} / \mathrm{kg}$ resulted in fibroblast proliferation values of 70.14 and $69.19 \%$ for the P2 group and K- group respectively. Overall, there were no significant differences among the treatments and controls.

\section{DISCUSSION}

In this study, ovariectomy caused a significant increase in SOD levels compared with controls. The increase in SOD levels in rat vaginas was accompanied by elevated levels of MDA, a marker of ROS formation. A previous study by Wiyasa reported a similar increase in SOD levels at 28 days post-ovariectomy [13]. Elevated SOD levels were also shown in osteoporosis postmenopause rats [14]. $\mathrm{Cu}, \mathrm{Zn}-\mathrm{SOD}$ is believed to have an important role as a major antioxidant defense enzyme [14]. Consistent with this possibility, Birben et al reported that this enzyme acts as a primary antioxidant preventing free radical formation by terminating the reaction and transforming free radicals into more stable compounds [15]. Estrogens has been found to be a potent antioxidant, which reduces oxidative physiological stress [15], while estrogen deficiency accelerates the aging process in women. Moreover, Al-Baghdadi et al reported a gradual increase in MDA levels resulting from ovariectomy in mice, which showed that estrogen loss led to oxidative stress [4].

(A)
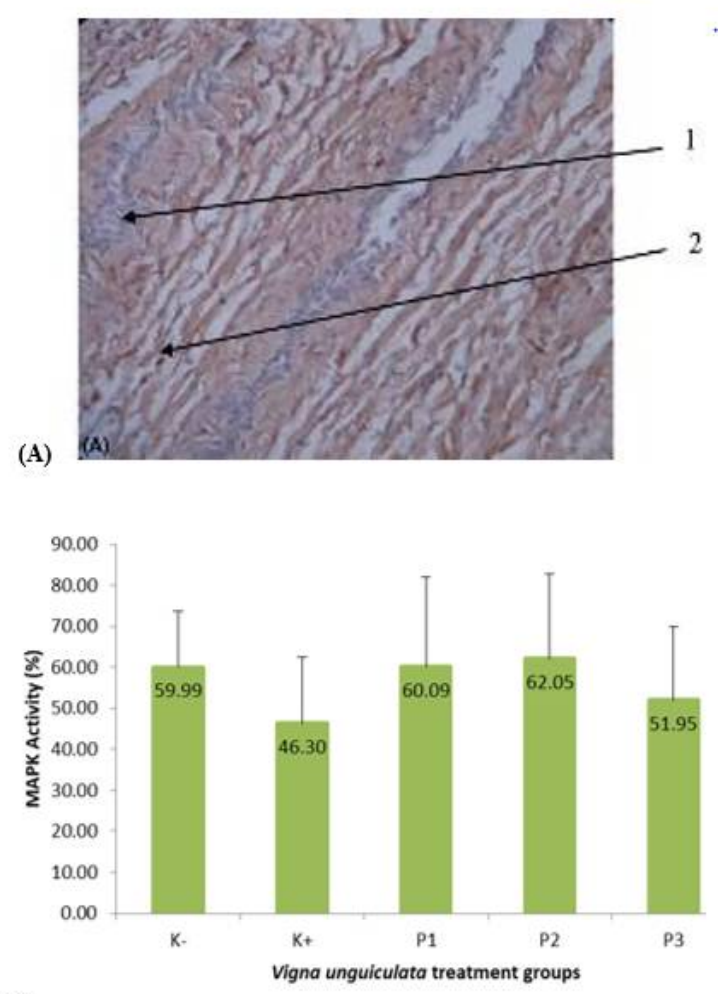

(B)

Figure 3: Effect of extract treatment on MAPK activity. (A) Immunohistochemistry using p-ERK $1 \frac{1}{2}$ MAPK antibody. No MAPK activity was observed in cells with blue color, and those with MAPK activity exhibited a brown color (400x magnification). (B) The quantification of areas showed that MAPK activity decreased after ovariectomy and increased after the administration of cowpea ( $V$. unguiculata) extract. There were no significant differences among the groups. $\mathrm{K}-$, negative control; $\mathrm{K}+$, untreated ovariectomized rats; $\mathrm{P} 1$, treated with $1.25 \mathrm{mg} / \mathrm{kg}$; $\mathrm{P} 2$, treated with $2.5 \mathrm{mg} / \mathrm{kg}$; and P3, treated with $5 \mathrm{mg} / \mathrm{kg}$ 


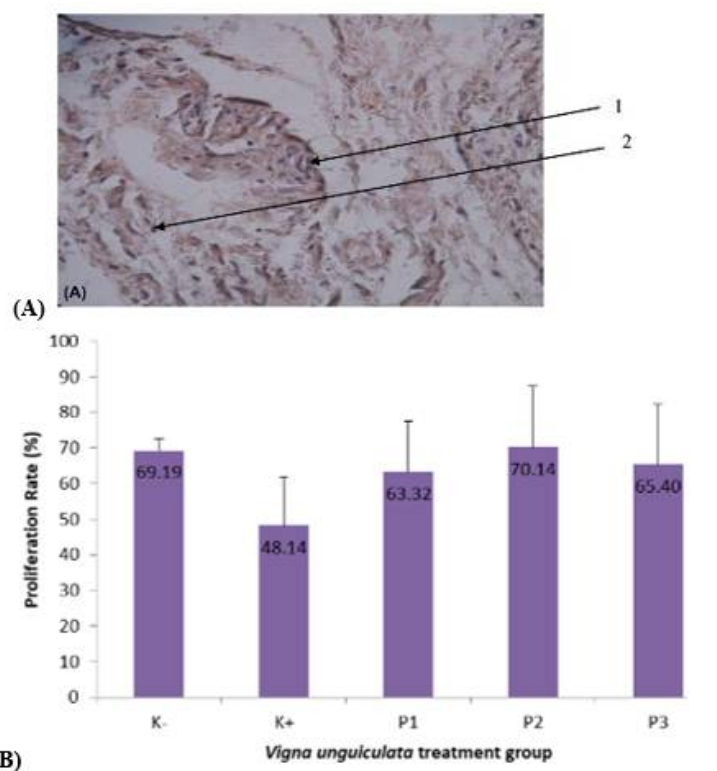

Figure 5: Efffect of extract treatment on fibroblast proliferation. (A) Fibroblast cells that showed no proliferative activity are indicated by blue color, while cells with proliferative activity have a brown color (400x magnification). (B) Quantification of cells that showed proliferation activity. Proliferation of fibroblasts decreased significantly after ovariectomy. Treatment with cowpea ( $V$. unguiculata) extract significantly increased fibroblast proliferation at all doses. K-, negative control; $\mathrm{K}+$, untreated ovariectomized rats; $\mathrm{P} 1$, treated with $1.25 \mathrm{mg} / \mathrm{kg}$; P2, treated with 2.5 $\mathrm{mg} / \mathrm{kg} ; \mathrm{P} 3$, treated with $5 \mathrm{mg} / \mathrm{kg}$

Cowpea ( $V$. unguiculata) is a source of various isoflavones such as genistein, quercetin, and daidzein, which have antioxidant and antiinflammatory properties [10]. Isoflavones have similar molecular structures as $17 \beta$ estradiol, and they also have estrogenic activity. These compounds bind directly to the same receptors as endogenous estrogen, resulting in an estrogenic effect [16]. Ozacmak and Sayan reported that $17 \beta$ estradiol and progesterone treatment reduced the MDA levels in rat brains after ovariectomy [2]. Furthermore, estrogen suppresses free radical formation, because $17 \beta$ estradiol treatment decrease MDA levels in the brains of ovariectomized rats.

In a manner similar to SOD levels, MDA levels decreased significant post-ovariectomy increases. This result was consistent with previous reports $[13,14]$, which showed that MDA levels gradually increased post-ovariectomy. This indicates that the loss of estrogen may increase oxidative stress levels [17]. Administration of cowpea ( $V$. unguiculata) extract at all doses resulted in significant reductions in MDA levels. This study also showed significant decreases in MDA levels after each treatment, with the lowest MDA level produced after treatment with 2.5 $\mathrm{mg} / \mathrm{kg} /$ day. Moreover, the dose of $1.25 \mathrm{mg} / \mathrm{kg}$ /day decreased the MDA level to the same level as that of normal rats. This result is also consistent with previous studies, which showed that treatment with cowpea ( $V$. unguiculata) extract reduced MDA levels in the heart [10] and blood serum [18].

Heart MDA levels were also significantly decreased in hypoestrogenic rats treated with cowpea (V. unguiculata) extract [19]. A similar result was reported by Ojwang, who reported that cowpea ( $V$. unguiculata) extract doses of 0.5 and $2.5 \mathrm{~mL} / \mathrm{kg}$ in rats resulted in decreased MDA levels [20]. It was therefore expected that cowpea ( $V$. unguiculata) extract treatment at 2.5 $\mathrm{mg} / \mathrm{kg}$ was the optimal dose for prevention of lipid peroxidation. Furthermore, isoflavone supplementation with $100 \mathrm{mg}$ of soya and 500 $\mathrm{mg}$ of calcium carbonate for $6-12$ months significantly decreased MDA levels in the serum of menopausal women [19].

Both $E R \alpha$ and $E R \beta$ can bind to isoflavones, with ER $\beta$ having the stronger affinity. ER $\beta$ therefore plays a pivotal role in the ovarium system, cardiovascular system, and brain [18]. Another mechanism of isoflavone control of MDA levels involves the hydroxyl group of the isoflavone, which acts as a hydrogen donor from the phenolic group to the peroxide radical [18]. Radical phenoxyl stability resulting from the reaction prevents the propagation of lipid peroxidation [14]. Therefore, free radical reactivity can be controlled, and radical antioxidants formed from the reaction will be decreased [13].

The MAPK signal transduction pathway works extracellularly, as well as intracellularly from the receptor to the genome. MAPK transduction signals can be affected by various conditions such as infection, pathogens, injury, temperature, dryness, irradiation, and pollution. Quercetin administration can affect MAPK pathway components, especially ERK, which is stimulated by growth factor signaling [20]. Quercetin has been reported to effectively reduce the quantity of phosphor-ERK1/2 protein [21]. Furthermore, MAPK signal transduction has been influenced by the quercetin content of cowpea ( $V$. unguiculata) extract that was used in this study. Furthermore, fibroblast proliferation was also affected by treatment with cowpea ( $V$. unguiculata) extract. Genistein, also known as one of the active compounds of cowpea ( $V$. unguiculata), has been previously reported to affect proliferation of the mammary gland [16]. 
Phytoestrogens have an effect similar to synthetic estrogen or drugs (hormone replacement therapy), which affect human health through genomic and non-genomic effects [2]. The isoflavone effect of cowpea ( $V$. unguiculata) extract during menopause involves the proliferation of the vaginal epithelium. Genistein in cowpea ( $V$. unguiculata) extract is similar to endogenous estrogens, but with a weak estrogenic effect. Genistein interacts with ERs to saturate the receptors, preventing binding of endogenous estrogens to the receptor. Genistein induces the effects of endogenous estrogens in menopausal women who have low levels of estrogen by binding to ER- $\alpha$ in the vagina [3].

Genistein also directly binds to the estrogen a stromal receptor, which activates a paracrine component involving the epidermal growth factor (EGF). EGF activation induces the activation of tyrosine kinases in the epithelium, and EGF and tyrosine kinase activate protein kinases in the cell cytoplasm. The activated kinases are MAPKs, which become the main activation and translation signals for protein synthesis required for mitosis of epithelial cells, and leading to epithelial cell proliferation. Furthermore, genistein can also repair the chromatin structure in the $\mathrm{ERa}$ promoter, contributing to ERa reactivation. Finally, genistein consumption can prevent cancer development and breast tumor growth in ERa-negative rats.

\section{CONCLUSION}

This study has shown that cowpea ( $V$. unguiculata) extract has a positive phytoestrogenic effect. Treatment with this extract significantly decreases SOD and MDA levels, but not MAPK activity or fibroblast proliferation. These findings suggest an optimal concentration of cowpea (Vigna unguiculata) extract of $2.5 \mathrm{mg} / \mathrm{kg}$ is required to reduce SOD and MDA levels.

\section{DECLARATIONS}

\section{Acknowledgement}

The authors thank Brawijaya University, Politechnic of Health, Ministry of Health, Malang, and Saiful Anwar Public Hospital for facilitating this research.

\section{Conflict of interest}

The authors declare that no conflict of interest is associated with this work.

\section{Contributions of authors}

We declare that this work was done by the authors named in this article and all liabilities pertaining to claims relating to the content of this article will be borne by the authors. AIS and IWAW: Research design; collection, analysis and interpretation of data; writing of the manuscript. RR: analysis and interpretation of data. IWAI: analysis, interpretation of data; and revision of the manuscript. All authors participated in the design of the study data, read and approved the final manuscript

\section{Open Access}

This is an Open Access article that uses a funding model which does not charge readers or their institutions for access and distributed under the terms of the Creative Commons Attribution License (http://creativecommons.org/licenses/by/ 4.0) and the Budapest Open Access Initiative (http://www.budapestopenaccessinitiative.org/rea d), which permit unrestricted use, distribution, and reproduction in any medium, provided the original work is properly credited.

\section{REFERENCES}

1. Rouskova D, Mittmann K, Schumacher U, Dietrich $H$, Zimmermann T. Effectiveness, tolerability and acceptance of a low-dosed estradiol/dienogest formulation (Lafamme $1 \mathrm{mg} / 2 \mathrm{mg}$ ) for the treatment of menopausal complaints: a non-interventional observational study over 6 cycle of 28 days. Gynecol Endocrinol 2015; 31(7): 560-564.

2. Al-Baghdadi O, Ewies AAA. Topical estrogen therapy in the management of postmenopausal vaginal atrophy: An up-to date overview. J Climacteric 2009; 12(2): 91 105.

3. Brouwers $O$, Niessen PM, Ferreira I, Miyata T, Scheffer $P G$, Teerlink T, Schrauwen P, Browniee M, Stehouwer $C D$, Schalkwijk CG. Overexpression of glyoxalase-I reduces hyperglycemia-induced levels of advanced glycation end products and oxidative stress in diabetic rats. J Biol Chem 2011; 286(2): 1374-1380.

4. Perry JJ, Shina DS, Getzoffa ED, Tainer JA. The structural biochemistry of the superoxide dismutases. Biochim Biophys Acta 2010; 1804(2): 245-262.

5. Pitzschke A, Hirt $H$. Mitogen activated protein kinase and reactive oxygen species signaling in plants. Plant Physiol 2006; 141(2): 351-356.

6. Kamato D, Burch ML, Piva TJ, Rezaei HB, Rostam MA, $X u S$, Zheng $W$, Little PJ, Osman N. Transforming growth factor- $\beta$ signaling: role and consequences of Smad linker region phosphorylation. Cell Signal 2013; 25(10): 2017-2024. 
7. Harjana T. Buku ajar histologi. Yogyakarta: Universitas Negeri Yogyakarta; 2011. 49 p.

8. Eroschenko VP. DiFiore's atlas of histology with functional correlation. USA: Lippincott Williams \& Wilkins; 2005. 198 p.

9. Darmadi D, Nurdiana, Eviana N. Efek ekstrak kacang tunggak terhadap osteoblas dan osteoklas pada tikus dengan ovarektomi. Jurnal Kedokteran Brawijaya 2011; 26(3): 151-155.

10. Khusniyati E, Sari AA, Yueniwati $Y$, Noorhamdani, Nurseta $T$, Keman $K$. The effects of Vigna unguiculata on cardiac oxidative stress and aorta estrogen receptor$\beta$ expression of ovariectomized rats. Asian Pac J Reprod 2014; 3(4): 263-267.

11. Khajuria DK, Razdan R, Mahapatra DR. Description of a new method of ovariectomy in female rats. Rev Bras Reumatol 2012; 52(3): 462-470.

12. Kirac FS. Is ethics approval necessary for all trials? a clear but not certain process. Mol Imaging Radionucl Ther 2013; 22(3): 73-75.

13. Wiyasa IWA. Peran genistein dalam meningkatkan pembentukan dan menghambat resorpsi tulang Rattus norvegicus wistar hipoestrogen melalui peningkatan superokside dismutase dan gluthation peroksidase [dissertation]: Brawijaya University, Malang, Indonesia; 2012; $p 89$.

14. Sanchez-Rodriguez MA, Zacarias-Flores M, ArronteRosales A, Correa-Munoz E, Mendoza-Nunez VM.
Menopause as risk factor for oxidative stress. Menopause 2012; 19(3): 361-367.

15. Birben E, Sahiner UM, Sackesen C, Erzurum S, Kalayci O. Oxidative stress and antioxidant defense. World Allergy Organ J 2012; 5(1): 9-19.

16. Behr M, OehImann J, Wagner M. Estrogens in the daily diet: In vitro analysis indicates that estrogenic activity is omnipresent in foodstuff and infant formula. Food Chem Toxicol 2011; 49(10): 2681-2688.

17. Seif $A A$. Nigella sativa reverses osteoporosis in ovariectomized rats. BMC Complement Altern Med 2014: 14-22.

18. Afif Z, Rahmawati D, Dalhar M, Widodo MA. Effect of ethanolic cowpea (Vigna unguiculata) extract on MDA, $S O D, T N F-\alpha$ levels and neuron cell in wistar rat brain after exposed with gasoline fume. IOSR J Environ Sci Toxicol Food Technol 2014; 8(2): vacuolation 113-118.

19. Ojwang LO. Anti-inflammatory properties of cowpea (Vigna unguiculata) phenotypes with different phenolic profiles [dissertation]: Texas A \& M University, Texas, USA; 2012. $121 \mathrm{p}$.

20. Chen AY, Chen YC. A review of the dietary flavonoid, kaempferol on human health and cancer chemoprevention. Food Chem 2013; 138(4): 2099-2107.

21. Meng FD, Li Y, Tian X, Ma $P$, Sui CG, Fu LY, Jiang $Y H$. Synergistic effects of snail and quercetin on renal cell carcinoma Caki-2 by altering AKT/mTOR/ERK1/2 signaling pathways. Int J Clin Exp Pathol 2015; 8(6): 6157-6168. 